\title{
Determinants of Milk Market Participation and Volume of Sales to Milk Collection Centres of the Smallholder Dairy Value Chain in Zimbabwe
}

\author{
Tafireyi Chamboko ${ }^{1}$, Emmanuel Mwakiwa ${ }^{1} \&$ Prisca H. Mugabe ${ }^{2}$ \\ ${ }^{1}$ Department of Agricultural Economics and Extension, University of Zimbabwe, Harare, Zimbabwe \\ ${ }^{2}$ Department of Animal Science, University of Zimbabwe, Harare, Zimbabwe \\ Correspondence: Tafireyi Chamboko, Department of Agricultural Economics and Extension, University of \\ Zimbabwe, P.O. Box MP 167, Mount Pleasant, Harare, Zimbabwe. Tel: 263-4-303-211. E-mail: \\ chamboko@agric.uz.ac.zw
}

\author{
Received: July 12, $2017 \quad$ Accepted: August 16, $2017 \quad$ Online Published: September 15, 2017 \\ doi:10.5539/jas.v9n10p156 URL: https://doi.org/10.5539/jas.v9n10p156
}

The research is financed by African Economic Research Consortium (AERC) based in Nairobi, Kenya.

\begin{abstract}
At the attainment of Zimbabwe's independence, government of Zimbabwe established the smallholder dairy development programme to encourage smallholder farmers to participate in formal milk markets. Although now more than three decades since the government established this programme, smallholder contribution to the national formal market remains low at 5\%. This study was undertaken to determine factors affecting milk market participation and volume of sales to milk collection centres of the smallholder dairy value chain. Four smallholder dairy schemes were purposively selected on the basis of whether the scheme participated in the semi-formal or formal dairy value chain. A total of 185 farmers were then selected through simple random sampling and interviewed using a pretested structured questionnaire. Data were analysed using descriptive statistics and Heckman two-stage selection econometric models. Results show that resources (represented by dairy cows, household size), knowledge (educational level, access to information and extension), experience (household head age) and agro-ecological region significantly determined farmers' participation in milk markets. The study also shows the determinants of milk sales volumes to be resources (number of dairy cows and landholding size); market access (distance to milk collection centre); ambition of the farmer (age); and natural climatic conditions (agro-ecological region). Government policy interventions therefore need to be targeted at increasing the number of dairy cows, taking into account landholding and market access, targeting educated, young farmers located in agro-ecological regions I and II, providing them with adequate, appropriate information and extension packages in order to enhance milk market participation and volume of sales.
\end{abstract}

Keywords: dairy scheme, formal, Heckman two-stage model, semi-formal, southern Africa

\section{Introduction}

At the attainment of Zimbabwe's independence in 1980, large scale commercial farmers supplied all the milk that entered the formal markets. Milk produced by smallholder farmers was mainly for subsistence purposes (Chavhunduka, 1982). The government of Zimbabwe established the smallholder dairy development programme in 1983 to encourage smallholder farmers to participate in formal milk markets (Chamboko \& Mwakiwa, 2016). By 2016, the smallholder dairy development programme was credited with facilitating the establishment of about 20 smallholder dairy schemes located in various parts of the country. These schemes have provided an avenue through which smallholder farmers participate in dairy production and marketing. A distinct feature of the smallholder dairy schemes are the milk collection centres and sub-centres that are run by farmer managed marketing cooperatives. The milk collection centres are responsible for bulking up the milk from the producers and are equipped with cooling facilities. Through the support of government and donors over the years, some of the milk collection centres have acquired and established milk processing facilities and are able to process the milk to produce mainly fermented milk (Amasi) and yoghurts. Smallholder dairy schemes that process milk at the milk collection centre participate in the semi-formal value chain, whereby the milk and milk products 
produced are largely sold to consumers within the local community in the rural areas and to nearby rural service centres or rural growth points. There are also smallholder dairy schemes that do not process the milk at the milk collection centre but deliver the milk to established urban based processors. These urban based dairy processors process the milk into various products such as Ultra-high temperature processing (UHT) milk, cheese, yoghurts, and dairy related beverages which are predominantly sold to consumers in the urban areas. The milk collection centres of the smallholder dairy schemes that supply milk to urban based processors participate in the formal dairy value chain. The smallholder dairy value chain therefore predominantly is comprised of the semi-formal and the formal dairy value chains.

Although it is now more than three decades since the government of Zimbabwe established the smallholder dairy development programme and subsequent smallholder dairy schemes and milk collection centres, milk delivered to the milk collection centres has not had significant impact on national volumes, only contributing $5 \%$ of the milk entering the formal markets. This is unlike other developing countries similar to Zimbabwe such as Kenya, where $80 \%$ of the milk entering the formal markets comes from smallholder farmers (Moll, Staal, \& Ibrahim, 2007). According to Muriuki and Thorpe (2002), in Eastern and Sothern Africa, with the exception of Zimbabwe and South Africa, dairy production is dominated by smallholder farmers. A number of studies have been carried out particularly in Eastern and Northern Africa to understand milk market participation and volume of supply to markets (e.g., Demissie, Komicha, \& Kedir, 2014 in Ethiopia; Balirwa, Nalunkuuma, \& Sserunkuuma, 2016 in Uganda). These studies indicate important socio-economic variables that are relevant in informing the development of interventions to improve market participation and productivity, which ultimately increases volume of milk sales from smallholder dairy producers. There is, however a paucity of milk market participation and volume of supply studies that have been performed in Southern Africa. This study therefore contributes to the literature on milk market participation and volume of supply studies. The objective of this study therefore is to assess the determinants of milk market participation and volume of milk sales to the milk collection centres of the smallholder dairy value chain in Zimbabwe in order to inform the development appropriate interventions that can enhance smallholder farmers' milk market participation and improvement in the volume of milk sales.

\section{Method}

\subsection{Description of Study Areas}

Four smallholder dairy schemes under the dairy development porgramme were purposively selected on the basis of whether there was milk collection centre processing (to supply the semi-formal value chain), linkages with established urban based processors (to supply the formal value chain), farming system (Note 1), agro-ecological or natural region (NR) (Note 2) location of the scheme, and performance in terms of daily deliveries of milk to the milk collection centre. Two schemes participating in the semi-formal value chain selected were Chikwaka and Nharira-Lancashire, and two supplying the formal value chain were Marirangwe and Rusitu smallholder dairy schemes. The characteristics of the selected study sites are summarized in Table 1.

Table 1. Characteristics of smallholder dairy schemes selected for the study, Zimbabwe 2015

\begin{tabular}{|c|c|c|c|c|}
\hline Smallholder Dairy Scheme & Chikwaka & Nharira-Lancashire & Marirangwe & Rusitu \\
\hline Value Chain & $\begin{array}{l}\text { Participates in } \\
\text { semi-formal }\end{array}$ & $\begin{array}{l}\text { Participates in } \\
\text { semi-formal }\end{array}$ & $\begin{array}{l}\text { Supplies Formal } \\
\text { value chain }\end{array}$ & Supplies Formal value chain \\
\hline Milk Processing & $\begin{array}{l}\text { Milk collection } \\
\text { centre processing }\end{array}$ & $\begin{array}{l}\text { Milk collection } \\
\text { centre processing }\end{array}$ & $\begin{array}{l}\text { Delivered to processors } \\
\text { (based in the capital city } \\
\text { of Harare) }\end{array}$ & $\begin{array}{l}\text { Delivered to Dairibord Zimbabwe } \\
\text { limited (privatised company of the } \\
\text { former state run Dairy Marketing } \\
\text { Board) }\end{array}$ \\
\hline $\begin{array}{l}\text { Agro-ecological location of the } \\
\text { scheme or natural region (NR) }\end{array}$ & NR II & NR III & NR II & NR I \\
\hline Farming system & Communal & $\begin{array}{l}\text { Encompasses both } \\
\text { Communal and Small } \\
\text { scale commercial }\end{array}$ & Small scale commercial & Old resettlement area \\
\hline $\begin{array}{l}\text { Total milk deliveries to } \\
\text { milk collection centre }\end{array}$ & Average 200 litres/day & Average 200 litres/day & Average 400 litres/day & Average 600 litres/day \\
\hline
\end{tabular}




\subsection{Sampling Techniques}

The lists of all members of the smallholder dairy schemes were obtained from the milk collection centres. The list included producers who were and those who were not delivering milk at the time of the study. These lists formed the sampling frames for the sample survey. The samples were selected from lists of 65 producers in Chikwaka, 125 producers in Nharira-Lancashire, 35 in Marirangwe and 245 in Rusitu. The objective was to interview at least 50 producers from each smallholder dairy scheme within the given time frame and available research resources. Simple random sampling was used to select the sample of farmers included in the study. Since the sampling frame for Marirangwe smallholder dairy scheme had less than 50 households, the sample of farmers included in the study were all the producers in the sampling frame. The total number of households interviewed in the four smallholder dairy schemes was therefore 185 farmers. This sample provides a cross section of farmers to represent determinants of market participation and volume of sales to the milk collection centres of the smallholder dairy value chain under different farming systems, agro-ecological potentials and varying scheme performance levels.

\subsection{Data Collection Methods}

Quantitative and qualitative data were collected from both primary and secondary sources. Primary data collected related to milk production and marketing in the smallholder dairy schemes while secondary data collected included statistics on milk deliveries to the milk collection centres and processors. The main sources of secondary data included the Zimbabwe National Statistics Agency (ZimStats), Department of Economics and Markets (from the Ministry of Agriculture, Mechanisation and Irrigation Development), Farmer Unions, Dairy processors such as Dairibord Zimbabwe Limited, Kefalos and the milk collection centres under the smallholder dairy development programme. Secondary data were also collected from Dairy Services which regulates the dairy industry, Zimbabwe Association of Dairy Farmers, and the Zimbabwe Dairy Industry Trust.

The main source of primary data included key informant interviews, focus group discussions and a survey of households of member farmers of the milk collection centres under the smallholder dairy schemes of the dairy development programme. Key informant interviews targeted the major stakeholders in the dairy industry and these included government institutions, private processors, milk collection centre staff and experienced farmers from the target smallholder dairy schemes. One focus group discussion per smallholder dairy scheme was held with representatives of smallholder dairy farmers. The household survey used a questionnaire that was pretested in Chikwaka smallholder dairy scheme, one of the study sites. The questionnaire collected data on household demographic characteristics, socio-economic data, inputs, milk production and sales, dairy herd data, access to information, extension services and credit, and milk market participation, among others. The data were collected by trained enumerators' during the period August to October 2015.

\subsection{Data Analysis}

Data entry was performed in Census and Survey Processing (CSPro) version 6.1, and was exported to and analysed using Statistical Package for the Social Sciences (SPSS) and STATA. Descriptive statistics were used to summarise household socio-economic and demographic characteristics. In order to describe the characteristics of households in the four schemes, producers selling milk to the milk collection centre at the time of the study were considered as milk market participants and those who did not as non-market participants. The Heckman two-step selection econometric models were used to analyse the determinants of milk market participation and volume of sales to the milk collection centre. The specification of the econometric models used in the study followed literature on empirical studies of selectivity models (Goetz, 1992; Key, Sadoulet, \& De Janvry, 2000; Holloway, Nicholson, Delgado, Staal, \& Ehui, 2004; Bellemare \& Barrett, 2006). The Heckman two-step is part of the selectivity models, in which the decision to participate in milk markets can be seen as a sequential two-stage decision making process. In the first stage, households make a discrete choice on whether to participate or not to participate in milk markets (that is, whether to deliver milk or not to the milk collection centre). In the second stage, conditional on their decision to participate, households make continuous decisions on volume of milk sales to the milk collection centre. In the first stage, the standard probit model which follows random utility model and specified as Wooldridge (2002) is used:

$$
\begin{gathered}
\mathrm{y}^{*}=\mathrm{z}^{\prime} \alpha+\varepsilon_{1} \\
\mathrm{y}=1, \text { if } \mathrm{y}^{*}>0 ; \mathrm{y}=0 \text { if } \mathrm{y}^{*} \leq 0
\end{gathered}
$$

Where, $\mathrm{y}^{*}$ is a latent (unobservable) variable representing household discrete decision to participate in milk market or not. $z$ ' is a vector of independent variables hypothesized to affect household decision to participate in milk market. $\alpha$ is a vector of parameters to be estimated which measures the effects of the explanatory variables 
on household's decision. $\varepsilon_{1}$ is normally distributed disturbance with mean $(0)$ and standard deviation of $\sigma_{1}$ and captures all unmeasured variables. $\mathrm{Y}$ is a dependent variable which takes on the value 1 if a household participates in milk market and 0 otherwise. Conditional on milk market participation, variables affecting the volume of milk sales to the milk collection centre were then modeled using the second-stage Heckman selection model (Heckman, 1979). The Heckman selection equation is specified as follows:

$$
\begin{gathered}
\mathrm{Z}_{\mathrm{i}}^{*}=\mathrm{w}_{\mathrm{i}} \alpha+\varepsilon_{2} \\
\mathrm{Z}_{\mathrm{i}}=\mathrm{Z}_{\mathrm{i}}^{*} \text { if } \mathrm{Z}_{\mathrm{i}}^{*}>0 ; \mathrm{Z}_{\mathrm{i}}=0 \text { if } \mathrm{z}_{\mathrm{i}}^{*} \leq 0
\end{gathered}
$$

Where, $Z_{i}^{*}$ is the latent variable representing optimal volume of milk sales to the milk collection centre, which is observed if $\mathrm{Z}_{\mathrm{i}}^{*}>0$ and unobserved otherwise. $\mathrm{Z}_{\mathrm{i}}$ is the observed volume of milk sold to the market, $\mathrm{w}_{\mathrm{i}}$ is the vector of covariates for unit $i$ for selection equation which is a subset of $z$ ', $\alpha$ is the vector of coefficients for selection equation and $\varepsilon_{2}$ is the random disturbance for unit $i$ for selection equation. One of the problems with the two Equations (1) and (2) is that the two-stage decision making processes are not separable due to unmeasured household variables affecting both discrete and continuous decisions thereby leading to errors of the equations. If the two errors are correlated, the estimated parameter values on variables affecting volume of milk sales are biased (Wooldridge, 2002). Thus the model that corrects selectivity while estimating volume of milk sales needs to be specified. For this purpose, in the first-step, Mills ratio is created using probability values obtained from the first-stage probit regression of milk market participation. Then in the second-step, the Mills ratio is then included as one of the independent variables in volume of milk sales regression. Thus volume of milk sales equation with correction for sample selection bias becomes:

$$
\mathrm{V}=\mathrm{w} \alpha+\lambda\left[\phi\left(\mathrm{w}_{\mathrm{i}} \alpha\right) / \Phi\left(\mathrm{w}_{\mathrm{i}} \alpha\right)\right]+\varepsilon_{3}
$$

Where, $\phi(.) / \Phi($.$) is the Mills ratio, \lambda$ is the coefficient on the Mills ratio, $\phi$ denotes standard normal probability density function, $\Phi$ denotes the standard cumulative distribution function and $\varepsilon_{3}$ is normally distributed disturbance term with zero mean and standard deviation of $\sigma_{3}$, and $\varepsilon_{3}$ is not correlated with $\varepsilon_{1}$ and $\varepsilon_{2}$ and other independent variables. Under the null hypothesis of no sample selection bias, $\lambda$ is not significantly different from zero. In this study, $\mathrm{V}$ is volume of milk sales in litres.

The independent variables were identified based on economic theories and empirical studies as follows (Table

\begin{tabular}{|c|c|c|}
\hline Variable & Description & Values, Expected Sign \\
\hline Age (Agehh) & Age of household head in years & Number of years, \pm \\
\hline Educational level (Educhh) & Educational level of head of household & Number of years in school, + \\
\hline Sex (Sexhh) & Sex of household head (Dummy: $1=$ male; $0=$ female) & + \\
\hline Household size (hhsize) & Number of household members & Number, + \\
\hline Distance to market (DistkmMCC) & Distance to the milk collection centre & $\mathrm{Km},-$ \\
\hline Access to extension (AccExt) & $\begin{array}{l}\text { Access to extension services in the dairy schemes } \\
\text { (Dummy: } 1=\text { yes; } 0=\text { no) }\end{array}$ & + \\
\hline Access to information (AccInfo) & Access to dairy enterprise information (Dummy: $1=$ yes; $0=$ no) & + \\
\hline Dairy farming experience (Dexp) & Dairy farming experience of the head of household & Number of years, + \\
\hline Total land holding of the household (Landho) & Total size of land holding of the household & Hectares, + \\
\hline Total number of dairy cows (TotCows) & Total number of dairy cows owned by the household & Number, + \\
\hline Income from other sources (InOthSou) & Income from other sourcers & USD \\
\hline Farmer occupation (FarOcc) & Occupation of the farmer (Dummy: $1=$ fulltime farmer; $0=$ otherwise) & + \\
\hline Agricultural training (AgriTr) & $\begin{array}{l}\text { Agricultural training of the head of household } \\
\text { (Dummy: } 1=\text { Received some training in agriculture; } 0=\text { otherwise) }\end{array}$ & + \\
\hline Agro-ecological or natural region (NRDSch) & $\begin{array}{l}\text { Agro-ecological location of the smallholder dairy scheme } \\
\text { of the household (Dummy: } 1=\text { Natural region I or II; } 0=\text { otherwise) }\end{array}$ & \pm \\
\hline Milk sold & Volume of milk sales to the milk collection centre & Litres/month \\
\hline Market Participation & $\begin{array}{l}\text { Farmers producing and selling milk to the milk collection centre } \\
\text { (Dummy: } 1=\text { yes; } 0=\text { no) }\end{array}$ & \\
\hline
\end{tabular}
2).

Table 2. Description of dependent and independent variables used in Heckman two-step selection model 


\section{Results}

\subsection{Socio-Economic and Demographic Characteristics of Milk Market Participants and Non-Participants}

About $87 \%$ of the 185 smallholder dairy producers interviewed were classified as market participants. The characteristics of households show that average age of the household head was about 57 years for market participants group and about 60 years for non-market participants group. The independent samples t-test for age was not significant between the two groups. The independent t-test for educational level of the household head, number of extension visits to the farm, total size of land holding of the household, size of household in terms of average number of household members, income from other sources, total number of dairy cows owned by the household and the volume of milk sales to the milk collection centre were significant at the $5 \%$ level of significance between participants and non-participants (Table 3). The Chi-square test for categorical variables shows that only access to information and the agro-ecological region location of the smallholder dairy scheme of the household were statistically significant between market participants and non-market participants (Table 3).

Table 3. Socio-economic and demographic characteristics of milk market participants and non-participants

\begin{tabular}{|c|c|c|c|}
\hline \multirow{2}{*}{ Variables } & \multicolumn{3}{|c|}{ Mean value of variables } \\
\hline & Market Participant & Non-Participant & t-value \\
\hline Age of household head (years) & 56.60 & 60.30 & -1.249 \\
\hline Educational level (number of years in school) & 8.98 & 7.50 & $2.172 *$ \\
\hline Distance to milk collection centre $(\mathrm{Km})$ & 5.30 & 6.20 & 0.872 \\
\hline Number of extension visits to the farm & 12.50 & 3.60 & $4.794 *$ \\
\hline Dairy farming experience (years) & 16.80 & 16.30 & 0.216 \\
\hline Total size of arable land $(\mathrm{Ha})$ & 8.30 & 2.10 & $4.492 *$ \\
\hline Household size & 6.30 & 5.30 & $2.031 *$ \\
\hline Total number of dairy cows owned & 4.60 & 1.40 & $6.946^{*}$ \\
\hline Income from other sources & 3248.00 & 1656.00 & $1.986^{*}$ \\
\hline \multirow[t]{2}{*}{ Milk sold per month (litres) } & 515.17 & 0.00 & $7.114^{*}$ \\
\hline & & & Chi-square value \\
\hline \multicolumn{4}{|l|}{ Sex of head of household } \\
\hline$\%$ Males & 73.90 & 73.90 & 0.000 \\
\hline \multicolumn{4}{|l|}{ Access to extension services } \\
\hline$\%$ Yes & 96.90 & 100.00 & 0.734 \\
\hline \multicolumn{4}{|l|}{ Access to information } \\
\hline$\%$ Yes & 75.80 & 26.10 & $23.469 *$ \\
\hline \multicolumn{4}{|l|}{ Farmer occupation } \\
\hline$\%$ fulltime & 81.9 & 78.3 & 1.74 \\
\hline \multicolumn{4}{|l|}{ Agricultural training } \\
\hline$\%$ received some training in agriculture & 55.3 & 47.8 & 0.451 \\
\hline \multicolumn{4}{|l|}{ Agro-ecological region } \\
\hline$\%$ in NR I and II & 68.9 & 100 & $9.808^{*}$ \\
\hline
\end{tabular}

Note. ${ }^{*}$ Statistical significance at $5 \%$.

\subsection{Results of the Heckman Model}

The results of the first-stage of the Heckman two-step model show that of the 14 variables included in the model, seven variables explained the probability of milk market participation. These were total number of dairy cows owned by the household (TotCows), educational level of the head of household (Educhh), age of the head of household (Agehh), size of household (hhsize), access to information (AccInfo), access to extension services (AccExt), and the agro-ecological location of the smallholder dairy schemes of the household (NRDSch). The variables were positive and significant (Table 4). 
Table 4. Results of first and second stage Heckman models

\begin{tabular}{|c|c|c|c|c|c|c|c|c|}
\hline \multirow{2}{*}{ Variable } & \multicolumn{4}{|c|}{ First stage model } & \multicolumn{4}{|c|}{ Second stage Heckman selection } \\
\hline & Coefficient & Standard Error & $\mathrm{z}$ & $\mathrm{P}>|\mathrm{z}|$ & Coefficient & Standard Error & $\mathrm{z}$ & $\mathrm{P}>|\mathrm{z}|$ \\
\hline TotCows & 0.0063 & 0.0032 & 1.97 & $0.049 * *$ & 0.4693 & 0.1636 & 2.87 & $0.004 *$ \\
\hline DistkmMCC & 0.0016 & 0.0016 & 1.02 & 0.308 & -0.1873 & 0.0649 & -2.89 & $0.004 *$ \\
\hline Eduhh & 0.0149 & 0.0025 & 5.48 & $0.000^{*}$ & -0.0836 & 0.0890 & -0.94 & 0.348 \\
\hline Agehh & 0.0037 & 0.0007 & 5.53 & $0.000^{*}$ & -0.0604 & 0.0268 & -2.25 & $0.024 * *$ \\
\hline Sexhh & 0.0114 & 0.0176 & 0.65 & 0.516 & 0.2836 & 0.5302 & 0.53 & 0.593 \\
\hline hhsize & 0.0072 & 0.0024 & 3.02 & $0.003^{*}$ & 0.0618 & 0.0841 & 0.73 & 0.463 \\
\hline Dexp & 0.0005 & 0.0010 & 0.47 & 0.641 & -0.0262 & 0.0278 & -0.94 & 0.346 \\
\hline LandHo & -0.0007 & 0.0005 & -1.28 & 0.202 & 0.5578 & 0.2414 & 2.31 & $0.021 * *$ \\
\hline AccInfo & 0.0491 & 0.1827 & 2.69 & $0.007 *$ & 0.6216 & 0.4763 & 1.31 & 0.192 \\
\hline AccExt & 0.4656 & 0.0452 & 10.31 & $0.000^{*}$ & 6.0513 & 2.1499 & 2.81 & $0.005^{*}$ \\
\hline IncOthSou & 0.0000 & 0.0000 & 0.37 & 0.711 & 0.0003 & 0.0002 & 1.30 & 0.193 \\
\hline FarOcc & 0.1681 & 0.0204 & 0.82 & 0.411 & 0.6840 & 0.6979 & 0.98 & 0.327 \\
\hline AgriTr & 0.0184 & 0.0158 & 1.16 & 0.245 & -0.6652 & 0.5535 & -1.20 & 0.229 \\
\hline NRDSch & 0.0640 & 0.0206 & 3.10 & $0.002 *$ & -3.4258 & 1.5765 & -2.17 & $0.030 * *$ \\
\hline Lambda & & & & & 0.0791 & 0.0369 & 2.14 & $0.032 * *$ \\
\hline
\end{tabular}

Note. First stage dependent variable $=$ Market participation through delivering milk to the milk collection centre; Second stage dependent variable $=$ Volume of milk sales to the milk collection centre per month in litres.

Number of observations $=144$, Censored observations $=17$, Uncensored observations $=127$.

First stage Wald $\mathrm{Chi}^{2}=16$ 181.68, $\mathrm{Prob}>\mathrm{Chi}^{2}=0.0000$; Second stage Wald $\mathrm{Chi}^{2}=2024.26, \mathrm{Prob}^{2} \mathrm{Chi}^{2}=0.0000$, Rho $=1.00000$, Sigma $=0.079621$.

$*, * *$ Statistical significance at $1 \%$ and $5 \%$, respectively.

The results of the second-stage Heckman selection estimation model for volume of milk sales to the milk collection centre of the smallholder dairy value chain show that out of the 14 variables six variables significantly affected the volume of milk sales to the milk collection centre. Total number of dairy cows owned by the household (TotCows), landholding size of the household (LandHo), and access to extension (AccExt) were positive and significant, while distance to the milk collection centre (DistkmMCC), age of the household head (Agehh), and agro-ecological region of the smallholder dairy scheme of the household (NRDSch) were negative and significant (Table 4).

\section{Discussion}

\subsection{Socio-Economic Characteristics of Milk Market Participants and Non-Participants}

Milk market participants sold milk to the milk collection centre, while the remaining households did not participate in the market. The milk collection centre forms an important stage of the smallholder dairy value chain. At two of the schemes studied (Chikwaka and Nharira-Lancashire), milk is processed on site at the milk collection centre and the dairy products are sold directly to consumers in the local area or nearby growth points and urban areas (regarded as the semi-formal value chain). Part of the milk is sold as raw milk to the local community or as fermented milk (Amasi). In the milk collection centres supplying the formal value chain (Marirangwe and Rusitu) the milk is collected by urban based processors who produce a number of products that are sold mainly to urban based consumers. Therefore participating in the semi-formal or formal value chain offers potentially better incomes for smallholder dairy producers.

The socio-economic characteristics of milk market participants and non-participants show that the age of the head of household was not significant but was lower for market participants (57 years) compared to non-market participants (60 years). The mean educational level of the household head in terms of number of years in school for market participants was higher ( 9 years) compared to non-market participants ( 8 years). The $\mathrm{t}$-statistic value indicated the mean difference in educational level was statistically significant and positive at $5 \%$ level. This indicates the importance of education in understanding and decision making of smallholder dairy producers in terms of market orientation. The results are consistent with the findings of Kuma, Baker, Getnet and Belay (2014). 
The mean distance to the milk collection centre was $5.3 \mathrm{Km}$ for milk market participants compared to non-market participants $(6.2 \mathrm{Km})$, and the t-statistic indicates this was not statistically significant. The results of dairy farming experience for the head of household also indicates the mean was not statistically different between participants and non-participants. The results of the size of landholding of the household show that milk market participants had larger mean landholding $(8.3 \mathrm{Ha})$ compared to non-market participants $(2.1 \mathrm{Ha})$. The t-statistic results of this variable were significant at $1 \%$ level, indicating the relationship between smallholder dairy market participation and size of landholding in Zimbabwe.

Households who participated in milk markets had larger household sizes (about 6 household members) compared to 5 household members for non-market participants, and the t-statistic showed the variable was significant at 5\%. Dairying is an intensive enterprise and most of the households in the smallholder dairy schemes depend on family labour. The results of mean household size indicates that size of household is an important resource for the dairy enterprise as it influences market participation due to the availability of labour for performing the various activities of the dairy enterprise.

The total number of dairy cows owned by the household for milk market participants was about 5 cows compared to one cow for non-market participants, and this was significant at $1 \%$. The quantity of milk sold per month was 515 litres, indicating that milk production is the most important variable affecting milk market participation. The results of income from other sources shows that milk market participants had higher incomes (USD3248) compared to non-milk market participants (USD1656) and this was significant at 5\%. Income from other sources such as crop production enables smallholder dairy producers to access resources to invest in the dairy enterprise, such as acquiring dairy cows of improved breeds. This therefore indicates the influence of other sources of income in milk market participation.

The results of the sex of head of household indicate about $74 \%$ of the heads were males for both milk market and non-milk market participants, and the Chi-square test was not significant. Access to extension services results show that about $97 \%$ and $100 \%$ of milk market participants and non-milk participants respectively had access to extension services and the Chi-square test indicates the difference was also not significant.

Access to information was measured on the basis of whether one of the household members owned a mobile phone, and whether the mobile phone was used to access dairy enterprise information. About $76 \%$ of milk market participants indicated positively to accessing information compared to about $26 \%$ of non-milk participants and the variable was significant. The results indicate the influence of access to information on milk market participation.

The last two categorical variables assessed were occupation of the household head and agro-ecological region location of the smallholder dairy scheme of the household. Occupation of the head of household was classified into full time farmers, or otherwise if the farmer was not fulltime on the farm. Fulltime time farmers were resident at the farm while others were employed off farm or were involved in other activities that limited them from farming on a full time basis. About $82 \%$ of milk market participants were full time farmers compared to $78 \%$ for non-milk market participants, although the Chi-square test indicates this was not significant. In terms of agro-ecological location of the smallholder dairy scheme of the household, about $70 \%$ of milk market participants were located in NR I and II, and all the non-milk market participants (100\%) were located in NR I and II, and the Chi-square indicates this variable was significant. In Zimbabwe, the natural region location of the household determines the amount of rainfall that is received and therefore the potential for agricultural and livestock production. NR I and II are considered as the regions with the highest potential for intensive production of both crops and livestock, compared to NR III to V where the rainfall is limited and the regions are suitable for semi-intensive and extensive crop and livestock production (Muir-Leresche, 2006).

\subsection{Determinants of Milk Market Participation and Volume of Sales}

\subsubsection{First-Stage Heckman Participation Model}

Results of the first stage Heckman two-step model (binary probit model) show that out of the 14 explanatory variables, seven were found to determine the probability of milk market participation. These are total number of dairy cows owned by the household, educational level of the head of household, age of the household head, household size, access to information and extension services, and agro-ecological region location of the smallholder dairy scheme of the household.

As expected, the total number of dairy cows owned by the household had positive relationship with milk participation decision and was statistically significant at $5 \%$ probability level. The positive and significant relationship indicates that the greater the number of dairy cows owned by the household, the better is the milk 
production and the more likely the household will make milk market participation decisions. These results are consistent with the findings of Kuma et al. (2014). The educational level of the head of household was positive and had significant impact on milk market participation at $1 \%$. The positive and significant relationship between the two variables indicates the educational level of the head of household as an important variable affecting household milk market participation. This also indicates educated dairy producers have some knowledge of the importance of market participation decisions. Age had positive and significant impact on milk market participation at $1 \%$. The positive and significant relationship indicates that age, which can be used as a proxy for experience, shows that old aged farmers acquire experience over the years and hence positively influences market participation. These results coincide with the findings of Kuma et al. (2014) and Mamo, Tefera, and Byre (2014) in Ethiopia.

The results show that household size and milk market participation relationship was positive and significant at $1 \%$. The results are in conformity with the findings of Demissie et al. (2014) in Ethiopia. The positive and significant relationship indicates that dairy is a labour intensive enterprise. Large family sizes in smallholder dairy enterprise indicates availability of labour for smallholder dairy production which increases milk market participation. Access to information and milk market participation decision are positively related and significant at $1 \%$. This indicates that access to information increases milk market participation and leads to understanding of the workings of the market, information on prices, and other market information that improves decision making of the smallholder dairy producer. Access to extension services and milk market participation decisions indicates a positive and significant relationship at $1 \%$. This indicates that access to extension services provides farmers with information on technologies that are necessary to improve management of the dairy enterprise and hence improved milk production and enhanced market participation decisions.

Agro-ecological region location of the smallholder dairy scheme of the households and milk market participation decisions relationship was positive and significant at $1 \%$. This indicates that agro-ecological region location of the scheme of the household enhances milk market participation decisions since smallholder dairy schemes located in high potential regions of NR I and II are able to access feeds and stover from crop production due to the high rainfall received in these regions. Households can also grow improved fodder crops for supplementary feeding of their dairy animals, compared to dairy schemes located in NR III to V. Masama, Kusina, Sibanda, and Majoni (2005) study of Nharira-Lancashire which is located in NR III of Zimbabwe found that farmers kept inadequate amounts of feeds of poor nutritional quality for feeding the dairy cows year round. Chinogaramombe et al. (2008) also found that shortages of feed was one of the major constraints for smallholder dairy production for the semi-arid regions of Zimbabwe which are mainly located in NR III, IV and V.

The results of the milk market participation model also show that distance to the market, sex of the head of household, dairy farming experience of the head of household, land holding size, farmer occupation, agricultural training of head of household, and income from other sources were not significant. In terms of landholding size and dairy farming experience, these results are contrary to the findings of Kuma et al. (2014) in Ethiopia. Kuma et al. (2014) found these two variables to be negatively related to milk market participation, which was contrary to their initial expectations. The explanation advanced (Kuma et al., 2014) in the case of dairy farming experience in Ethiopia was that households with many years dairy farming experience owned local cows and lived in areas where the demand for milk was low. The farmers were also more engaged in marketing milk products rather than milk. In Zimbabwe, this could possibly be explained by the fact that dairy farmers have not adopted dairy farming as a specialized enterprise and are therefore not commercially oriented. Key informant interviews indicates that farmers practicing dairy are also into many other cropping and livestock enterprises and therefore do not give dairying the management attention it requires as a specialized enterprise.

In terms of landholding size, Kuma et al. (2014) found a negative and significant effect on household milk market participation. Their explanation was that the negative relationship between milk market participation and land holding indicates that market oriented dairy production does not necessarily require large pieces of land (Kuma et al., 2014). This was mainly because households producing milk for market had access to purchasing pastures from other households or from government holdings. Contrary to the situation reported by Kuma et al. (2014), in Zimbabwe, farmers do not have access to purchased pastures from other households. The households have to allocate the available land between competing demands for the production of food crops, fodder and feed for the smallholder dairy enterprise.

Although the results of income from other sources were not significant in this study, other studies have found otherwise. Demissie et al. (2014) found that financial income from other sources had negative effect on cow milk market participation in Ethiopia and the relationship was significant. Demissie et al. (2014) explanation was that 
this indicated that any financial income decreases milk market participation for the smallholder producer household as a result of fixed transaction costs.

The determinants of farmers' participation in the milk market can be summarized as follows: dairy cows and household size represent availability of resources; whilst educational level, access to information and extension service represent availability of knowledge; age of household head represent experience; and agro-ecological region represent the natural and climatic conditions.

\subsubsection{Second-Stage Heckman Selection Model}

Heckman's second stage estimation identifies the significant factors that affect volume of milk sales using the selection model which included the inverse Mill's ratio calculated from the probit estimation of milk market participation decision. The overall joint goodness of fit for the second stage is assessed based on Wald Chi-square test. The null hypothesis for the test is that all coefficients are jointly zero. In this study, the model Wald Chi-square test (Wald $\mathrm{Chi}^{2}=2024.26$; $\mathrm{Prob}>\mathrm{Chi}^{2}=0.0000$ ) indicates that the overall goodness of fit for the selection model is statistically significant at less than $1 \%$. This shows that jointly independent variables included in the model explained the volume of milk sales.

In the second stage selection model, out of the 14 variables, seven variables were found to be significant determinants of volume of milk sales to the milk collection centre of the smallholder dairy value chain, including the inverse Mill's ratio (LAMBDA). The variables found to be significant are total number of dairy cows owned by the household, distance to the milk collection centre (representing access to markets), age of the head of household, land holding size of the household, access to extension services and agro-ecological region location of the smallholder dairy scheme of the household.

As hypothesized, the total number of dairy cows owned by the household has positive effect on volume of milk sales and is significant at the $1 \%$ probability level. The model output predicts that an addition of one dairy cow causes the marketable volume to increase by 0.47 litres per month. The number of dairy cows owned by the household is an important policy variable that indicates possible policy interventions that can be implemented to enhance milk market participation and volume of milk sales for the smallholder dairy producers to benefit from the lucrative value chains. Bardhan, Sharma, and Saxena (2012) study in India report the milk output sold depends on farm and farmer specific variables such as family size, age, education, resource ownership like land and animal holding. In this study, resource ownership includes total number of dairy animals owned by the household which are significant in determining volume of sales.

The distance to the milk collection centre, which was used as a proxy for access to milk markets of the smallholder dairy value chain, was negative and significant at $1 \%$ probability level. As hypothesized, distance to the milk collection centre affected milk sales volume negatively. This indicates that as one moves further away from the milk collection centre, the greater the transportation costs and the losses due to spoilage and less access to information and facilities offered by the milk collection centre, thereby impacting negatively on volume of milk sales.

Age of the head of household had negative effect on volume of milk sales and was found to be significant at $5 \%$. This implies that old aged households' heads are slow to adapt to changing market conditions and new technologies, and therefore do not respond quickly to market incentives to increase milk supply to the market. Conversely, this indicates that young aged household heads are more business minded, are ambitious and entrepreneurial and therefore make use of improved inputs to increase milk production, thus increasing volume of sales. The descriptive results show that generally the mean age of the household head for milk market participants was lower than that of non-milk market participants. This therefore indicates that old aged households are not as market oriented compared to young aged households. This implies that to increase the volume of milk sales to the milk collection centres of the smallholder dairy value chain, government policy interventions need to target young aged households that are more adaptable, ambitious and entrepreneurial, and are more inclined to quickly understand the dynamics of the milk markets.

Land holding size of the household had a positive and significant effect on milk sales volume at $5 \%$. This indicates that households with large land holdings have better access to grazing for their dairy cows, and can also grow supplementary fodder crops including better access to crop residues that can be used as supplementary dairy feed. This improves milk production and hence milk sales volume supplied to the milk collection centre of the smallholder dairy value chain. The results of the descriptive statistics show that generally land holding size was higher for smallholder milk market participants. This indicates an important policy variable that is relevant to smallholder milk sales volume, and has important implications for milk supply in Zimbabwe in light of the 
implementation of the fast track land reform and redistribution programme that has resulted in reduced sizes of land holdings of the previously large scale commercial farmers.

Access to extension services had positive and significant (at $1 \%$ level) effect on milk sales volume supplied to the milk collection centre of the smallholder dairy value chain. The change in having access to extension services of the smallholder dairy producers on milk quantity supplied was about 6.1 litres. The result indicates that milk sales volume in the study areas was more responsive to access to extension services. Extension is important in providing up-to-date knowledge required to effectively run the dairy enterprise. The policy implications are that access to adequate and appropriate extension should be one of the priority policy interventions if government is to increase milk sales volume from the smallholder dairy producers. This would increase milk production and hence milk sales volume to the milk collection centres of the smallholder dairy value chain.

The agro-ecological region location of the smallholder dairy scheme of the household had negative and significant effect on milk sales volume at $5 \%$. The results indicate that agro-ecological region location of the dairy scheme in areas other than NR I and II have negative effect on milk sales volume. This is mainly because livestock production in Zimbabwe depends on native pastures and use of crop residues (Masama et al., 2005). Natural regions I and II are considered high potential areas due to the high rainfall received (average $1050 \mathrm{~mm}$ and $750 \mathrm{~mm}$, respectively). This enables smallholder dairy producers in these areas to access crop residues from crop production that can be fed to dairy cows. Masama et al. (2005) found that the herd size influenced the quantities of supplementary feeds harvested and stored. The policy implications are that government policy interventions should target smallholder dairy producers in the high potential natural regions I and II if the milk sales volume is to be increased from the smallholder dairy schemes.

According to the model output, the inverse Mill's ratio or selectivity bias correction factor (LAMBDA) affected milk sales volume positively at 5\% significance level and indicates that in the Heckman two-step model, the correction for selectivity is significant. This indicates sample selection bias, and existence of some unobservable household characteristics affecting likelihood to participate in milk market and thereby affecting milk sales volume.

The determinants of volume of milk sales are thus number of dairy cows and landholding size of the household representing availability of resources; distance to the milk collection centre representing market access; age of household head representing ambition of the farmer; and agro-ecological region.

\section{Conclusions}

The study shows that resources (represented by dairy cows, household size), knowledge (educational level, access to information and extension services) and experience (age of household head) and natural climatic conditions (agro-ecological region) significantly determined farmers' participation in milk markets. The study also shows the determinants of milk sales volumes to be resources (number of dairy cows and landholding size of the household); market access (distance to the milk collection centre); ambition of the farmer (age of household head); and natural and climatic conditions (agro-ecological region). The results of the study suggest the following policy implications and interventions if milk market participation and sales volume are to be increased from the smallholder dairy schemes and hence increased supply of milk to the milk collection centre of the smallholder dairy value chain. In order to increase milk market participation, government policy interventions need to be targeted at increasing the number of dairy cows for smallholder dairy producers. Policy interventions should also target educated, young aged farmers located in high potential agro-ecological regions I and II. These should be provided with adequate and appropriate information and extension packages in order to enhance milk market participation decisions. The results also indicate that in order to increase milk sales volume to the milk collection centre of the smallholder dairy value chain, policy interventions targeted at increasing the number of cows owned by the smallholder dairy producers would have a positive impact. Complimentary policy interventions need to take into account the landholding size and agro-ecological region location of the smallholder dairy scheme of the household, the provision of adequate and appropriate extension messages targeted at smallholder dairy producers. Government would also need to implement policy measures that target young aged producers, and ensure the milk collection centres are accessible to the smallholder dairy producers if milk sales volume is to be increased to supply the milk collection centres of the smallholder dairy value chain.

\section{Acknowledgements}

A PhD thesis grant from the African Economic Research Consortium (AERC) based in Nairobi is acknowledged. However, the views expressed in the paper reflect the authors' views, and not of any other person. The Department of Livestock and Veterinary Services in the Ministry of Agriculture, Mechanization and Irrigation Development is greatly appreciated for facilitating data collection with introductions in the respective 
smallholder dairy schemes. The researcher would also like to acknowledge the assistance of enumerators with field data collection in the respective dairy schemes and the farmers who participated in the survey.

\section{References}

Balirwa, E. K., Nalunkuuma, J., \& Sserunkuuma, D. (2016). Determinants of smallholder dairy farmers' volume of milk sales in Uganda's agro-ecological zones. International Journal of Applied and Pure Science and Agriculture, 2(8), 97-109. Retrieved from http://ijapsa.com/published-papers/volume-2/issue-8/determinan ts-of-smallholder-dairy-farmers-volume-of-milk-sales-in-ugandas-agro-ecological-zones.pdf

Bardhan, D., Sharma, M. L., \& Saxena, R. (2012). Market participation behaviour of smallholder farmers in Uttarakhand: A disaggregated analysis. Agricultural Economics Review, 25(2), 243-254.

Bellemare, M. F., \& Barrett, C. B. (2006). An ordered Tobit model of market participation: Evidence from Kenya and Ethiopia. American Journal of Agricultural Economics, 88(2), 324-337. https://doi.org/10.1111/ j.1467-8276.2006.00861.x

Chamboko, T., \& Mwakiwa, E. (2016). A review of smallholder dairy development in Zimbabwe 1983 to 2013: The effect of policies. Livestock Research for Rural Development, 28, Article \#113. Retrieved June 3, 2016, from http://www.lrrd.org/lrrd28/6/cham28113.html

Chavhunduka, G. L. (1982). Report of the commission of inquiry into the agricultural industry. To the President 1982, Harare, Zimbabwe.

Chinogaramombe, G. N. C., Muchenje, V., Mapiye, C., Ndlovu, T., Chimonyo, M., \& Musemwa, L. (2008). Challenges for improving smallholder dairy production in the semi-arid areas of Zimbabwe. Livestock Research for Rural Development, 20, Article \#34. Retrieved from http://www.lrrd.org/lrrd20/3/ chin20034.htm

Demissie, B., Komicha, H. H., \& Kedir, A. (2014). Factors affecting camel and cow milk marketed surplus: The case of eastern Ethiopia. African Journal of Agricultural Science and Technology, 2(2), 54-58. Retrieved from https://www.oceanicjournals.com/ajast/pdf/2014/Feb/XXXXX\%20et\%20al..pdf

Goetz, S. J. (1992). A selectivity model of household food marketing behaviour in Sub-Saharan Africa. American Journal of Agricultural Economics, 74(2), 444-452. https://doi.org/10.2307/1242498

Heckman, J. J. (1979). Sample selection bias as a specification error. Econometrica, 47, 153-161. https://doi.org/10.2307/1912352

Holloway, G., Nicholson, C., Delgado, C., Staal, S., \& Ehui, S. (2004). A revised Tobit procedure of mitigating bias in the presence of non-zero censoring with an application to milk-market participation in the Ethiopian highlands. Agricultural Economics, 31, 97-106. https://doi.org/10.1111/j.1574-0862.2004.tb00224.x

Key, N., Sadoulet, E., \& De Janvry, A. (2000). Transactions Costs and Agricultural Household Supply Response. American Journal of Agricultural Economics, 82, 245-259. https://doi.org/10.1111/0002-9092.00022

Kuma, B., Baker, D., Getnet, K., \& Belay, K. (2014). Factors affecting milk marketing participation and volume of supply in Ethiopia. Asian Journal for Rural Development, 4, 1-15. https://doi.org/10.3923/ajrd.2014.1.15

Mamo, T., Tefera, T., \& Byre, N. (2014). Factors influencing urban and peri-urban dairy producers' participation in milk value addition and volume of milk value added in Welmera Woreda, West Shewa Zone of Oromia Regional State, Ethiopia. International Journal of Livestock Production, 5(9), 165-172. https://doi.org/ 10.5897/IJLP2013.0174

Masama, E., Kusina, N. T., Sibanda, S., \& Majoni, C. (2005). Farm-grown feed resources as factors affecting smallholder dairy production in Zimbabwe. African Crop Science Conference Proceedings, 7, 555-560.

Moll, H. A. J., Staal, S. J., \& Ibrahim, M. N. M. (2007). Smallholder dairy production and markets: A comparison of production systems in Zambia Kenya and Sri Lanka. Agricultural Systems, 94(2), 593-603. https://doi.org/10.1016/j.agsy.2007.02.005

Muir-Leresche, K. (2016). Agriculture in Zimbabwe. In M. Rukuni, P. Tawonezvi, C. Eicher, M. Munyuki-Hungwe, \& P. Matondi (Eds.), Zimbabwe's Agricultural Revolution Revisited. University of Zimbabwe Publications, Harare, Zimbabwe.

Muriuki, H. G., \& Thorpe, W. (2002). Smallholder Dairy Production and Marketing in Eastern and Southern Africa: A Regional Synthesis. Smallholder Dairy Production and Marketing-Opportunities and Constraints (pp. 185-200). Annad, India: NDDB and ILRI. 
Wooldridge, J. M. (2002). Econometric Analysis of Cross Section and Panel Data (p. 752). MIT Press, Cambridge, MA.

\section{Notes}

Note 1. The main types of smallholder farming systems considered were communal where the type of tenure is communal, small scale commercial with leasehold or freehold tenure and resettlement where the tenure is a permit (Muir-Leresche, 2006).

Note 2. Zimbabwe is divided into five agro-ecological regions or natural regions (NR) on the basis of rainfall. NR I receives about $1050 \mathrm{~mm}$ rainfall per annum, NR II (750-1050 mm), NR III (500-700 mm), NR IV (450-600 $\mathrm{mm}$ ) and NR V (less than $500 \mathrm{~mm}$ ) (Muir-Leresche, 2006).

\section{Copyrights}

Copyright for this article is retained by the author(s), with first publication rights granted to the journal.

This is an open-access article distributed under the terms and conditions of the Creative Commons Attribution license (http://creativecommons.org/licenses/by/4.0/). 